\title{
Manajemen Produksi Program Mimbar Agama TVRI Riau-Kepri
}

\author{
Ismandianto $^{1,}$ Neneng Susi Susilawati ${ }^{2}$ \\ ${ }^{1,2}$ Universitas Riau \\ ismandianto@lecturer.unri.ac.id
}

Received: October 10, 2020; Revised: February 20, 2021; Accepted: February 23, 2021

\begin{abstract}
Abstrak
Program mimbar agama merupakan program pendidikan mengenai keagamaan yang ditayangkan secara live di TVRI Riau, dengan mengangkat tema yang berbeda-beda setiap minggunya sesuai dengan agama masing-masing, yaitu: Islam, Kristen Protestan, Khatolik, Budha dan Hindu yang diisi oleh narasumber yang berbeda. Penelitian dilakukan untuk melihat manajemen produksi program acara dengan menggunakan teori POAC yaitu perencanaan, pengorganisasian, penggerakan, dan pengawasan. Penelitian ini menggunakan metode deskriptif kualitatif. Teknik pengumpulan dilakukan dengan observasi, wawancara dan dokumentasi. Pengambilan narasumber dengan menggunakan pertimbangan tertentu sesuai dengan tujuan penelitian. Informan dalam penelitian ini sebanyak empat orang yaitu produser program, pengarah acara serta pengisi acara. Hasil dari penelitian ini yaitu: Pertama membuat susunan acara program mimbar agama mulai dari perencanaan isi dan biaya. Kedua membuat susunan kerabat kerja yang bertugas dalam pelaksanaan perencanaan produksi program. Ketiga penggerakan produksi program secara live di TVRI Riau yang melibatkan semua kru yang telah ditentukan dan yang terakhir pengawasan terhadap acara tersebut dengan cara evaluasi yang diakukan oleh produser program secara langsung.
\end{abstract}

Kata Kunci: program; manajemen; agama; televisi.

\begin{abstract}
The religious pulpit program is an educational program on religion that is broadcast live on TVRI Riau, with a different theme each week according to their respective religions, namely: Islam, Protestant Christianity, Catholicism, Buddhism and Hinduism filled with different sources.. The research was conducted to see the production management of the program using POAC theory, namely planning, organizing, mobilizing, and controlling. This study used descriptive qualitative method. Data collection techniques are the result of observation, interviews and documentation. Retrieval of sources by using certain considerations in accordance with the objectives of the study. The informants in this study were four people, namely program producer, program director and performers. The results of this study are: First, make arrangements for the religious pulpit program starting from content planning and cost planning. Second, make the arrangement of work relatives who are in charge of implementing program production planning. The third is the movement ofprogram production live on TVRI Riau involving all predetermined crews and the last one is supervision of the event by means of evaluation carried out by the program producer directly
\end{abstract}

Keywords: program; management; religious; television. 


\section{Pendahuluan}

Perkembangan teknologi dan informasi dari zaman ke zaman semakin maju, ini menjadikan bangsa di dunia sangat melek terhadap perkembangan informasi dan kejadian yang ada di dunia ini, untuk memenuhi kebutuhan dari informasi. Teknologi semakin berkembang mendukung adanya media baru (Su Cin. 2020). Media menjawab kebutuhan masyarakat untuk mendapatkan informasi dengan cepat, tidak hanya sebatas mendapatkan informasi saja, media juga memberikan hal lainnya kepada masyarakat seperti serangkaian ilmu pengetahuan dan hiburan bagi para penggunannya seperti yang dilakukan TVRI Riau, di Indonesia sudah diatur dalam P3SPS (pedoman prilaku penyiaran standar program siaran) yang disusun oleh KPI melalui keputusan No.9 Tahun 2004 dan harus dipenuhi oleh setiap stasiun penyiaran.

Pedoman prilaku penyiaran merupakan panduan tentang batasanbatasan mengenai apa yang diperbolehkan dan tidak diperbolehkan berlangsung dalam proses pembuatan (produksi) program siaran, sedangkan standar program siaran merupakan panduan tentang apa yang diperbolehkan dan yang tidak ditayangkan dalam program siaran (Taufiqqurrahman 2013). media penyiaran harus mampu memenuhi kepentingan masyarakat (komunitas) dimana media bersangkutan berada sebagai ketentuan yang harus dipenuhi ketika media penyiaran bersangkutan menerima izin siaran (lisensi) yang diberikan negara, (Morrisan, 2009).
Televisi memiliki tujuan dalam menyampaikan pesan yang bisa menginformasikan, mendidik, menghubungkan, menghibur dan memberikan ilmu pengetahuan kepada masyarakat, dengan menjalankan fungsi itu setiap stasiun televisi berupaya memenuhi hal-hal tersebut melalui programprogramnya, seperti yang dilakukan LPP TVRI, menyediakan berbagai program yang mendidik, menghibur dan ilmu pengetahuan, salah satunya program mimbar agama.

Televisi Republik Indonesia merupakan lembaga penyiaran negara siarannya ditujukan untuk kepentingan negara. Peraturan pemerintah nomor 9 tahun 2002 TVRI berubah statusnya menjadi PT. TVRI (Persero) dibawah pembinaan kantor menteri negara BUMN menjadikan televisi diposisi strategis dalam memberikan informasi ke masyarakat di berbagai propinsi di Indonesia.

Era pertelevisian di provinsi Riau dimulai dengan hadirnya stasiun produksi TVRI Pekanbaru yang diresmikan oleh Menteri Penerangan pada tanggal 03 November 1998 yang saat ini berganti nama TVRI Riau Kepri. Wadah informasi masyarakat riau dan kepulauan riau yang memberikan warna melayu, serta memuat nilai kearifan lokal, agama. Program yang mendidik yang diproduksi TVRI salah satunya adalah program mimbar agama.

Program mimbar agama diproduksi sejak tahun 2006 dengan durasi penayangan selama 60 menit, program ini adalah sebuh program 
yang mendidik, konten yang berisi 5 keagama, yaitu: Agama Islam, Kristen Protestan, Katolik, Budha dan Hindu. Produksi program televisi memerlukan manajemen yang tepat karena melibatkan banyak tenaga kerja, peralatan dan biaya yang besar, untuk memproduksi suatu acara agar hal-hal yang tidak diinginkan terjadi maka penting untuk menggunakan manajemen dalam menggelola suatu produksi acara.

Program mimbar agama di TVRI tayang dua kali setiap bulannya yaitu minggu pertama dan minggu kedua dalam satu bulannya dengan agama yang berbeda-beda sesuai dengan jadwal yang telah ditentukan. Dimasa pandemi covid19 program mimbar agama kadangkala tidak tayang secara live di studio TVRI, tetapi program ini tetap tayang seperti biasanya dengan cara ply back.

Mengelola sebuah program membutuhkan sistem manajerial yang dapat membantu memudahkan pembagian tugas dan pekerjan di bidangnya masing-masing yang terlibat dalam proses produksi. Acuan yang digunakan untuk melihat bagaimana terapan manajemen produksi program acara mimbar agama yaitu dengan menggunakan teori yang telah dikemukakan George Terry mengenai fungsifungsi manajemen yaitu: POAC, POAC merupakan sebuah akronim yang cukup dikenal dalam kajian manajemen, meliputi Planning (perencanaan), Organizing (pengorganisasian), Actuating (Peggerakan) dan Controlling (pengawasan), (Siswanto and $\mathrm{Si}$ 2006).
Keberhsilan media peyiaran bergantung pada bagaimana kualitas orang-orang yang bekerja pada tiga bidang tersebut, namun demikian kualitas manusia saja tidak cukup jika tidak disertai dengan kemampuan pimpinan media penyiaran bersangkutan mengelola sumber daya manusia yang ada.Karena alasan inilah yang baik mutlak diperlukan pada media penyiaran, (Morrisan 2009)

Adapun tujuan penelitian bardasarkan permasalahan yang dikemukakan diatas adalah untuk mengetahui perencanaan, pengorganisasian, proses penayangan dan pengawasan program mimbar agama di TVRI Riau-Kepri.

\section{Kerangka Teori}

\subsection{Teori Manajemen}

$\begin{array}{ccr}\text { Dalam } & \text { penelitian } & \text { ini } \\ \text { menggunkan } & \text { model } & \text { yang } \\ \text { disampaikan } & \text { George } & \text { Robert }\end{array}$ Terry1985 menyatakan, modelmodel yang ada di dalam manajemen adalah serangkaian sub bagian tubuh yang berada dimanajemen sehingga dibagian-bagian tubuh tersebut dapat melaksanakan model dalam mencapai tujuan dalam organisasi yaitu, Organizing, Actuacing, Controling, (Winardi, 2008).

Manajemen adalah suatu
proses untuk menciptakan, memelihara, dan mengoperasikan, organisasi perusahaan dengan tujuan tertentu melalui upaya manusia yang sistematis, terkoordinasi dan koporatif maka proses penentuan asas-asas pokok perusahaan yang menjadi batasan, pedoman,dan penggerak bagi setiap manusia dalam 
perusahaan, sudah termasuk dalam pengertian manajemen, (Suprapto 2009).

\subsection{Produksi Media Televisi}

Tujuan produksi televisi adalah menerjemahkan narasi naskah tertulis menjadi sebuah audio visual. Konsep-konsep spot televisi iklan harus menerapkan kosa kata pengisahan cerita visual yang sejak awal dominan dalam media ini.Yang paling penting dalam media ini adalah bagaimana gagasan besar dapat dikomunikaikan melalui penekanan pada citra visual, dengan kata-kata yang terucapkan sedikit mungkin. Ciri yang dimiliki televisi adalah bahwa media ini memiliki gambar-gambar bergerak. Bukanlah pilihan yang baik untuk menyiarkan intruksi-intruksi atau menyodorkan daftar-daftar informasional

Dari semua media komuikasi yang ada, televisi yang paling berpengaruh pada kehidupan manusia. Sebanyak 99\% orang Amerika memiliki televisi di rumahnya. Tayangan televisi mereka dijejali hiburan, berita dan iklan. Mereka menghaiskan waktu menonton telivisi sekitar tujuh jam dalam sehari (Agge, et. al. 2000).

\section{Metode Penelitian}

Penelitian ini mengunakan penelitian kualitatif dengan pendekatan deskriptif, yang mana pada penelitian ini lebih menekankan pada cara pandang manajemen produksi program acara Mimbar Agama di LPP TVRI Riau-Kepri berkenaan dengan masalah yang diteliti. Metode kualitatif berusaha memahami dan menafsirkan makna suatu pristiwa interaksi tingkah laku manusia dalam situasi tertentu menurut perspektif penelitian sendiri, (Usman n.d.)

Adapun yang menjadi informan yang diteliti dengan menggunakan metode Purposive, yaitu pengambilan informan dengan menggunakan pertimbanganpertimbangan tertentu yang sesuai dengan ciri-ciri spesifik yang dimilikinya dari peneliti (Nurudin 2017). Informan dalam penelitian ini terdiri 4 orang karyawan TVRI Riau yaitu Hendri sebagai produser program Mulyadi sebagai pengarah acara, Ali Akbar sebagai kameramen dan M. Yusuf sebagai dekorasi panggung acara. Teknik pengumpulan data dengan cara observasi, wawancara dan dokumentasi. Analisis data dilakukan dengan cara sistematis pedomanan wawancara dan data kepustakaan, dengan tahapan reduksi data, menyajikan data, dan menyimpulkan.

Menurut (Moleong 2005) mendefinisikan analisis data adalah proses mengorganisasikan data sehingga dapat dirumuskan hipotesis yang disarankan oleh data. Intrepestasi data adalah memberikan arti yang singnifikan terhadap analisis, menjelaskan pola uraian, dan mencari hubungan diantara dimensi (Kriyantono 2010)

\section{Hasil Penelitian dan Pembahasan}

Manajemen sangat dibutuhkan sebagai acuan agar segala sistem kegiatan produksi dapat dilaksanakan dengan lancar dan efisien sesuai tujuan dan saran yang ditetapkan dan melalui upaya manusia yang sistematis, terkoordinasi dan 
koporatif (Suprapto 2009). Salah satu fungsi manajemen adalah Planning (perencanaan), fungsi perencanaan ini adalah tahapan standard operation procedur (SOP) proses produksi masuk kedalam tahap pra-produksi.

Perencanaan itu sendiri menurut (Djojosuroto 2006) meliputi penetapan tujuan, penetapan aturan, penyusunan rencana, dan sebagainya. Menggelola sebuah program membutuhkan sistem manajerial yang dapat membantu memudahkan pembagian tugas dan pekerjaan dibidangnya masingmasing yang terlibat dalam proses produksi program mimbar agama yaitu dengan menggunakan konsep manajemen produksi, menurut (Cangara 2013) dalam proses produksi memiliki beberapa tahapan yang harus dilakukan, tahapan itu adalah pra produksi, produksi, dan pasca produksi.

\subsection{Manajemen Perencanaan} Produksi Program Mimbar Agama Perencanaan program mimbar agama memiliki beberapa tahap yang dilakukan pihak TVRI yaitu: Pertama perencanaan isi dalam program mimbar agama, isi dalam program Mimbar Agama ini dibuat sesuai kebutuhan masyarakat beragama sesuai dengan kepercayaan atau agama masing-masing. Seperti penyampaian isi dari narasumber yang mengisi acara Mimbar Agama tersebut, isi yang disampaikan narasumber tentu saja mengenai pendidikan keagamaan untuk setiap agama, misalnya Mimbar Agama Islam materi yang disampaikan yaitu mengenai pendidikan Agama Islam begitupun untuk agama-agama lain.
Isi atau materi dari narasumber untuk masing-masing agama, pembukaan oleh presenter, pembacaan ayat suci Al-Quraan dan saritilawah, penyampaian isi dari tema, kemudian tanya jawab antara audiens dan ustad terakhir penutup untuk agama islam, kemudian penampilan nyanyian lagu pujipujian untuk tuhan yang menganut atau kepercayaan agama Kristen dan khatolik pembukaan dan penyampaian isi dari tema yang diangkat pada hari tersebut dan terakhir penutup, untuk agama hindu dan budha pembukaan oleh presenter, kemudian penyampaian isi dari tema yang diangkat narasumber, biasanya juga ada doa-doa kemudian terakhir penutup.

Gambar. 1 Program Acara Mimbar Agama

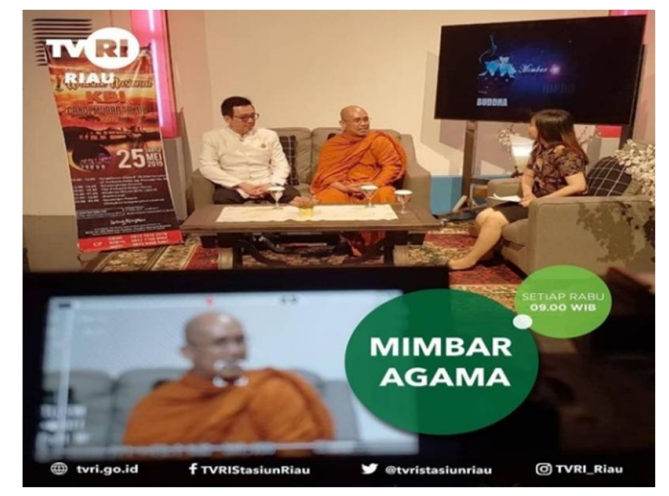

Sumber : TVRI Riau-Kepri

Isi dari program setiap agama berbeda sesuai dengan tema dan narasumber yang diangkat. TVRI bekerjasama dengan kementerian agama wilayah riau dalam menentukan tema yang diangkat yang sesuai dengan fenomena yang terbaru di masyarakat. Jadwal pengisi acara atau narasumber sudah ditentukan pihak kementrian agama melalui rapat dengan ketua atau 
perwakilan setiap agama yang akan mengisi program setiap dua kali dalam satu bulan. Minggu pertama Islam, minggu kedua Mimbar Agama Budha, minggu ketiga Agama Kristen, minggu keempat Agama Khatolik dan minggu kelima Mimbar Agama Hindu.

"Jadwal tahun bergatian. Jika pengisi acara berhalangan hadir 4 hari sebelum live agama bersankutan sudah memberi tahu pihak TVRI hal tersebut, setelah pihak TVRI dapat informasi tersebut maka pihak TVRI menghubungi narasumber agama lain untuk mengisi acara. Namun apabila pengganti juga belum siap untuk mengantikannya maka pihak TVRI melakukan play back atau mengulang kembali tema yang sudah pernah ditangkan sebelumnya" (wawancara Mulyadi 14 Oktober 2020)

Kedua perencanaan biaya untuk program program tergolong kecil, karena dalam memproduksi program ini narasumber, presenter dan audien tidak di bayar, divisi keuangan hanya mengeluarkan biaya untuk kebutuhan dekorasi panggung dan komsumsi untuk pengisi acara mimbar agama.

"Pengisi acara seperti narasumber, presenter tidak dibayar oleh pihak TVRI, karena pihak TVRI bekerjasama dengan kementrian agam Provinsi Riau. Dalam perjanjian biaya acara ditanggung oleh kementrian agama" (wawancara Mulyadi 26 November 2020)

Perencanaan pembiayaan seperti yang dikemukakan oleh Koontz dan Cyril (Suwardi 2006) yaitu budget, tujuan yang ingin dicapai dan bentuk nilai ekonomis, serta dana atau biaya yang disediakan untuk mencapai tujuan itu, tidak akan berjalan lancar, oleh sebab itu perencanaan biaya produksi harus dipirkirkan secara matang.

4.2 Manajemen Pengorganisasian Program Mimbar Agama

Pengorganisasian merupakan proses pemberian tugas, pengolakasian sumber daya serta pengaturan kegiatan secara terkoordinasi kepada setiap individu dan kelompok untuk menerapkan rencana (Suprapto 2009). Pengorganisasian dalam sebuah produksi sangat penting supaya apa yang disusun dari mulai perencanaan dapat terlaksanakan dengan baik dan sukses. Susunan organisasi program mimbar agama sebagai berikut :

Tabel 1. Kerabat Kerja Mimbar Agama TVRI Riau

\begin{tabular}{|l|l|l|}
\hline No & Nama & Jabatan \\
\hline $\mathbf{1}$ & Syarifudin, SE, MM Camong, S.PT. & $\begin{array}{l}\text { Produser Prongang Jawab Proram } \\
\text { Pengembangan Usaha }\end{array}$ \\
\hline $\mathbf{2}$ & $\begin{array}{l}\text { Suhardi } \\
\text { M.I.Kom }\end{array}$ & Produser Program \\
\hline $\mathbf{3}$ & Hendri Mulyadi, SP & Kameramen \\
\hline $\mathbf{4}$ & Ali Akbar & Kameramen \\
\hline $\mathbf{5}$ & Martin & Kameramen \\
\hline $\mathbf{6}$ & Ronal & Pengarah Acara \\
\hline $\mathbf{7}$ & Mulyadi & Dekorasi \\
\hline $\mathbf{8}$ & M. Yusuf & Dekorasi \\
\hline $\mathbf{9}$ & Jefri &
\end{tabular}

Sumber :TVRI Riau, 2020 
Pengorgnisasian bertujuan untuk menepatkan tim kerja pada posisi yang tepat sesuai kemampuan dan keahlian individu masingmasing, memaksimalkan kinerja untuk dapat meningkatkan hasil dari kinerja. Pengalaman yang dimiliki individu sebaiknya dipertimbangkan juga supaya kelancaran dalam kerja bisa teratasi. Pembahasan krabat kerja program mimbar agama selain memiliki kemampuan dalam bidangnya, profesional dan bertanggung jawab.

4.3 Manajemen Penggerakan Program Mimbar Agama

Tahapan Produksi, penggerakan adalah kegiatan-kegiatan menggerakan orang-orang beserta fasilitas penunjangnya agar penyelenggaraan pencapaian tujuan itu berjalan lancar sesuai dengan yang telah direncanakan, penggerakan ini terbagi atas melaksanakan tugas, memproduksi, mengemas produk, menjual produk, dan lain-lain, (Djojosuroto 2006).

Penggerakan program acara pertama dilakukan menghubungkan pengisi acara program mimbar agama kemudian setelah itu membicarakan temannya dengan narasumber menegenai tema yang akan di angkat pada acara mimbar agama tersebut, kemudian baru membuat administrasi atau surat izin produksi kepada pimpinan sebagai laporan kegiatan, setelah di acc oleh pimpinan surat izin produksinya, tim produksi tinggal menunggu jadwal yang telah ditentukan untuk produksi program Mimbar Agama.

Pengarah acara, adalah orang yang melakukan koordinasi. Pertama dilakukan sebelum program mimbar agama tayang, membahas tentang tema apa yang akan diangkat pada program mimbar agama minggu tersebut. Kedua, menentukan tema, serta narasumber. Kemudian ketiga, presenter sesuai dengan agama dan kepercayaan masing-asing agama. Narasumber datang ke lokasi 1 jam sebelum acara selanjutnya narasumber diberi penjelasan sekmen, mempersiapkan audio, make up dan keperluan lainnya.

Penggerakan selanjutnya yang akan dilakukan di studio yaitu pengarah acara (PA) yang akan memberi segala arahan untuk semua kru yang bertugas pada hari tersebut, mulai dari dekorasi panggun yang set dekornya harus sesuai untuk mimbar agama yang akan mengisi program mimbar agama pada saat itu, kemudian kameramen yang sudah siap dengan kameranya untuk pengambilan gambar. Pengisi acara sudah dipersiapkan dan clip on kemudian kru yang bertugas untuk mengoperasikan komputer master control untuk on air memasukan gambar ke siaran pemancar sudah stanbay, kemudian di sekitaran pengisi acara terdapat satu asisten pengarah acara yang siap mengarahkan segala sesuatu kepada pengisi acara dan kameramen sesuai dengan perintah pengarah acara yang berada diruangan master control melalui HT (Handy talky).

"Sejak covid 19 mewabah acara mimbar agama secara live dari studio mengalami kendala. Namun tetap terjadi penayangan pada minggu pertama dan minggu kedua setiap satu bulannya"., 
wawancara Hendri Mulyadi 14 Oktober 2020.

4.4 Manajemen Pengawasan Program Mimbar Agama

Tahapan Pasca-Produksi, Tahapan ini semua kegiatan setelah pengambilan gambar sampai materi itu ditayangkan selesai dan siap disiarkan (Morrisan 2009). Dalam tahap ini Controling meliputi pengawasan terhadap pelaksanaan tugas, menyeleksi produk acara agama, mengevaluasi penjualan, dan sebagainya. Pengawasan berarti juga pengevaluasian penilaian dan perbaikan.

Evaluasi, pengawan dilakukan agar produksi berjalan dengan baik tanpa ada kendala, biasanya pengawan dilakukan produser dalam program mimbar agama ini mengenai narasumber yang kadan kurang komunikatif dalam menyampaikan materi, biasanya produser untuk meminimalisir kesalahan saat produksi adalah dengan mengadakan rapat dengan seluruh kru produksi supaya kedepannya dapat lebih memilih narasumber yang komunikatif dan dapat menyampaikan materi dengan baik, karena diprogram mimbar agama ini kekuatannya pada dialog penyampaian isi narasumber, jadi semakin menarik yang disampaikan narasumber maka semakin berkualitas pula acaranya.

Pengawasan untuk kru-kru bagian kameramen, dekorasi dan pengarah acara di program mimbar ini jarang sekali ada kesalahan karena semua yang bertugas adalah orang-orang professional dan ahli dibidangnya masing-masing, biasanya asisten pengarah acara yang terlambat memberi catatan tentang title pengarah acara, nama dan lain sebagainya kepada pengarah acara sehingga ketika sudah on air nama pengisi acara belum siap untuk dimasukan dilayarpemancar, kemudian kru yang tidak datang pada saat produksi ini salah satu penghabat dalam produksi.

Bentuk pengawasan yang dilakukan dalam program mimbar agama langsung dilakukan oleh produser program mimbar agama. Evaluasi program membahas tentang kekurangan-kekurangan yang terjadi selama produksi seperti narasumber mimbar agama yang kurang komunikatif agar kedepannya dapat mencari narasumber yang lebih komunikatif dalam menyampaikan materi dengan tujuan supaya penonton dapat mengambil pelajaran dari narasumber tersebut.

Evaluaasi selanjutnya mengenai kinerja seluruh kru yang bertugas, agama, bagi kru yang tidak hadir pada saat produksi dievaluasi. Selanjutnya bagi asisten pengarah acara supaya lebih tanggap dan lebih cepat dalam mengcross cek pengisi acara agar dapat lebih cepat memberi cantatan mengenainama, jabatan dan title narasumber dan semua pengisi acara kepada pengarah acara dengan tujuan supaya pada saat on airnama pengisi acara dapat langsung muncul dilayar televisi.

Manajemen pengawasan bukan hanya mengawasi produksi program agar sesuai perencanaan saja, melainkan juga cara menciptakan innovasi-innovasi (pengembangan yang dilihat dari pengalaman untuk menciptakan hal yang baru untuk menunjang kualitas 
program mimbar agama) bagi program mimbar agama selanjutnya.

\section{Simpulan}

Berdasarkan penelitian yang telah dilakukan mengenai manajemen yang dilakukan dalam manajemen produksi proram mimbar agama di TVRI Riau, maka dapat ditarik kesimpulan sebagai berikut :

1. Perencanaan program mimbar agama ialah membuat susunan acara program, dalam program mimbar agama memiliki dua tahap yaitu perencanaan isi dan perencanaan biaya. Perencanaan isi program mimbarr agama ini dirancang mulai dari latar belakang terciptannya program, contec dan jam tayang siarannya. Latar belakang terciptanya program mimbar agama ini ialah program yang menayangkan pendidikan tentang keagamaan yang sesuai dengan kepercayaan masing-masing masyarakat Riau dan meningkatkan kesadaran beragama sesuai dengan kepercayaan masing-masing. Contec dalam program mimbar agama ini ialah tentang isi dari tema yang disampaikan oleh narasumber setiap pegisi masingmasing mimbar agama tersebut. Jam siaran program mimbar agamayaitu pada pukul 17:0018:00 WIB secara live di TVRI Riau. Sedangkan perencanaan biaya program mimbar agama yaitu tentang biaya yang dikeluarkan untuk produksi yaitu peneluaran dana untuk dekorasi panggung dan konsumsi pengisi acara.
2. penggorganisasian program mimbar agama di TVRI Riau adalah susunan kerabat kerja yang bertuas dalam pelaksanaan perencanaan produksi program mimbar agama. Didalam produksi program mimbar agama terdapat penanggung jawab produksi, produser program \& pengembangan usaha, produser program mimbar agama, pengarah acara, kameramen, dekorasi panggung dan on air.peran dalam kerabat kerja ini sangat berperan penting dalam produksi program mimbar agama, karena dengan keahlian yang dimiliki personil dan penepatan posisi yan sesuai akan menciptakan produksi yang bagus dan sesuai dengan perencanaan tanpa kendala apapun, sehingga informasi yang ingin disampaikan dalam program ini dapat dimenerti oleh masyarakat yang menonton.

3. penggerakan dalam produksi program mimbar agama di TVRI Riau ialah semua perencanaan yang awalnya hanya diatas kertas akan diaplikasikan kedalam produksi yang sesunguhnya, mulai dari setiap teori yang dirancang pada perencanaan isi diperaktekan dalam produksi, latar belakang terciptanya program, contec program sampai ke jam tayang program mimbar agama dikerjakan oleh seluruh kerabat kerjayang telah terorganisisir.

4. pengawasan program mimbar agama di TVRI Riau adalah salah satu fungsi manajemen perencanaan, pengorganisasian dan penggerakan sesuai dengan manajemen produksi dalam 
program mimbar agama dengan baik. Pengawasan dalam produksi program mimbar agama dipimpin langsung oleh produser program mimbar agama tersebut yang berfungsi agar program ini berjalan sesuai dengan perencanaan. Pengawasan pegerakan program mimbar agama ini dilakukan supaya bisa menjadi acuan untuk menciptakan perencanaan program yang lebih menarik lagi berupa innovasi.

\section{Saran}

Berdasarkan kesimpulan yang telah dipaparkan diatas, ada

\section{Daftar Pustaka}

Agee, Warren K, Philip H. Ault dan Edwin Emery, 2000. Introduction To Mass Communications, New York: Longman

Cangara, Hafied. 2013. Perencanaan \& Strategi Komunikasi. Jakarta: PT RajaGrafindo Persada.

Djojosuroto, Kinayati. 2006. Analisis Teks Sastra \& Pengajarannya. Pustaka.

Kriyantono, Rachmat. 2010. "Teknik Praktis Riset Komunikasi Jakarta: Kencana Perdana Media Group."

Moleong, Lexy J. 2005. "Metodologi Kualitatif Edisi Revisi, Bandung: PT." Remaja Rosdakarya.

Morrisan, M A. 2009. Periklanan Komunikasi Pemasaran Terpadu. Kencana.

Nurudin. 2017. Perkembangan Teknologi Komunikasi. jakarta: Rajawali Pers.

Siswanto, H B, and M Si. 2006. "Pengantar Manajemen, PT." Bumi masukan yang ingin penulis sampaikan dalam memproduksi proram mimbar agam di TVRI Riau yaitu dalam produksi program mimbar agama ini sepertinya membutuhkan beberapa penambahan untuk pengisi acara seperti agama Kristen, khatolik, hindu dan budha sebagai audiens, agar ada segmen Tanya jawab dengan narasumber supaya lebih menarik, kemudian adanya Tanya jawab antara penonton dengan narasumber agar masyarakat dapat mengerti dari penyampaian narasumber dengan baik

Aksara, Jakarta.

Su Cin. 2020. Konvergensi Media Baru dalam Penyampaian Pesan Melalui Podcast. Jurnal koneksi untar. Vol.4.no.2.hal.235242.https://journal.untar.ac.id/inde x.php/koneksi/article/view/8113/5 834

Suprapto, Tommy. 2009. Pengantar Teori \& Manajemen Komunikasi. Media Pressindo.

Suwardi, Purnama. 2006. "Seputar Bisnis Dan Produksi Siaran Televisi." Pa-dang: TVRI Sumatra Barat.

Taufiqqurrahman, Moh. 2013. "NilaiNilai Pendidikan Karakter Dalam Kebudayaan Melayu Yang Tersirat Dalam Gurindam Duabelas Karya Raja Ali Haji."

Usman, Husaini. No Title Metodologi Penelitian Sosial. jakarta: bumi aksara. 